\title{
SABOR DE VIDA ETERNA: APUNTES SOBRE LA INEFABILIDAD EN SAN JUAN DE LA CRUZ
}

\author{
Clovis Salgado Gontijo \\ Faculdade Jesuíta de Filosofia e Teologia, Belo Horizonte, Brasil \\ clovisalgon@gmail.com
}

\section{INTRODUCCIÓN}

En su consagrada obra The Varieties of Religious Experience, William James presenta la inefabilidad como uno de los cuatro trazos distintivos de la experiencia mística. Según el autor, siempre acompaña al sujeto místico la consciencia, de carácter negativo, de que los contenidos por él aprehendidos y saboreados no se pueden satisfactoriamente transmitir o registrar por medio verbal (James 159).

De este modo, se plantea un problema: dada la insuficiencia de la palabra frente a lo inefable, ¿estaría proscrita la posibilidad de un discurso sobre la experiencia mística? Los innumerables relatos de los místicos, provenientes del cristianismo y también de otras tradiciones, nos muestran que la inefabilidad, más que un impedimento, se ofrece como un desafío a la exigencia interna de comunicación de la experiencia. Así, no paraliza del todo el hablar místico, sino que solicita nuevos modos de configuración y tratamiento del lenguaje.

En tal discurso confrontado por su propio límite, se debe necesariamente incluir la referencia a la inefabilidad, de lo contrario, la esencia de lo experimentado se vaciaría. Al examinar específicamente el repertorio de la mística cristiana, observamos que muchos de sus textos suelen referirse a la inefabilidad, sea por vía directa -afirmándola a partir de términos pertenecientes al campo semántico de lo inexpresable-sea por vía indirecta -sugiriéndola a través de metáforas y de construcciones que no parecen "caber" en el marco del logos demostrativo-.

Este es precisamente el caso de San Juan de la Cruz, maestro espiritual que elige como una de sus principales imágenes didácticas y poéticas la Noche oscura, escenario privativo en el cual se camina trascendiendo no solo los apetitos, las concepciones, las fantasías, los recuerdos y los deseos personales, sino también el lenguaje hecho en conformidad con el restricto entendimiento humano. Al lado de esa clásica alusión al misterio incognoscible e inexpresable, la obra sanjuanista se encuentra llena de menciones directas a la inefabilidad. 
A primera vista, la afirmación de lo inefable podría sonar, por un lado, como una actitud contradictoria en un contexto que insiste en hacer uso de la palabra y, por otro, como una información infructífera, puesto que nada parece acrecentar además de un "juicio analítico", es decir, del reconocimiento de la incomunicabilidad verbal.

Sin embargo, en la presente nota pretendemos mostrar que al recurrir a la inefabilidad, San Juan de la Cruz nos ayuda a descubrir otros relevantes "trazos" de la experiencia mística y de los temas interpretados por él como inefables. Como veremos, uno de esos "trazos" permitirá incluso la superación de la aparente paradoja implícita en un discurso acerca de lo inexpresable. De este modo, esbozaremos aquí breves consideraciones sobre cuatro pasajes de la obra del santo carmelita que se refieren directamente a la inefabilidad. A partir de ellos, examinados sin una preocupación cronológica, intentaremos contestar, siempre que sea posible, a las siguientes interrogantes: ¿a qué se refiere, en cada contexto, la inefabilidad? ¿qué características la acompañan? ¿de qué modo se podría lidiar con ella expresivamente? ¿cuál sería el propósito de expresar verbalmente lo inexpresable? A fin de reflexionar acerca de estos puntos, estableceremos un diálogo entre las obras de San Juan de la Cruz y de Vladimir Jankélévitch, recurriendo eventualmente a otros autores modernos y contemporáneos, como Goethe, Susanne Langer, George Steiner, María Zambrano y Jean Baruzi, quienes también nos permitirán profundizar la cuestión de la inefabilidad.

Antes de empezar nuestro recorrido, cabe justificar la elección de un filósofo del siglo XX como principal base teórica para el estudio de un concepto presentado por un místico del siglo XVI. Jankélévitch es uno de los principales pensadores, en la historia de la filosofía occidental, en dedicarse al descompás entre el lenguaje verbal (demostrativo, discursivo) y ciertas experiencias humanas. Los títulos de muchas de sus obras -Debussy et le mystère (1949); Le Je-ne-sais-quoi et le Presque-rien (1957); La música y lo inefable (1961); Fauré et l'inexprimable (1974); Quelque part dans l'inachevé (1978)-ya señalan el lugar de destaque otorgado al misterio inefable en su pensamiento. Al lado de estos títulos, algunos de los conceptos fundamentales desarrollados por el autor conciernen igualmente al registro de lo incognoscible y de lo inexpresable, a saber: lo indecible (indecible), lo inefable (ineffable), lo inacabado (inachevé), el "no-sé-qué" (je-ne-saisquoi), lo nocturno. Y tanto para formular como para emplear tales conceptos, que implican por sí mismos una aproximación negativa (apofática), Jankélévitch recurre sobre todo al neoplatonismo, a los Padres de la Iglesia y a la mística cristiana, ámbitos que sostienen con frecuencia la naturaleza supraesencial del principio de la realidad. Así, aunque se declare agnóstico, el filósofo francés extrae de tradiciones dirigidas a un horizonte de trascendencia, un método y "herramientas" teóricas en sintonía con el misterio que identifica especialmente en el nivel de la inmanencia. Entre los místicos cristianos que le sirven de apoyo para el tratamiento de lo inexpresable se encuentra San Juan de la Cruz' . Del universo sanjuanista, Jankélévitch explora el "no-sé-qué” y el balbuceo (ambos

1 Como explica Enrica Lisciani-Petrini, San Juan de la Cruz es uno de los autores que, poco explorados por los intelectuales franceses contemporáneos, influencian al filósofo: 
presentes en la séptima canción del Cántico espiritual), así como el símbolo nocturno (Subida del Monte Carmelo; Noche oscura; Cantar del alma que se huelga de conocer a Dios por fe; Cántico espiritual, canción 15) y la "música callada" (Cántico espiritual, canción 15), oxímoron que, como otros identificados en la literatura mística, le invita a crear sus propios oxímoros ${ }^{2}$. Como veremos, aunque los "objetos" inefables abordados por Jankélévitch se extiendan más allá de la esfera mística privilegiada por la inefabilidad experimentada y tematizada por San Juan de la Cruz, la reflexión jankélévitchiana conserva, por su genealogía, muchos de los trazos originales de lo inefable místico, contribuyendo, de este modo, a un estudio de carácter especulativo del tema elegido. Además, la obra de Jankélévitch posee la sutileza necesaria para que desvelemos algo de los escritos sanjuanistas, que, llenos de matices en su lenguaje y contenido, ya encantaban al filósofo por su raro refinamiento (Jankélévitch, De la musique au silence 346).

Y también es de saber, que tanto más sutil y delicado es el toque y tanto más deleite y regalo comunica donde toca, cuanto menos tomo y bulto tiene el toque. Este toque divino ningún bulto ni tomo tiene, porque el Verbo que le hace es ajeno de todo modo y manera, y libre de todo tomo y figura y accidentes, que es lo que suele ceñir y poner raya y término a la sustancia; y así este toque de que aquí se habla, por cuanto es sustancial, es a saber, de la divina sustancia, es inefable. (...)

De donde la delicadez del deleite que en este toque se siente es imposible decirse; ni yo querría hablar en ello, porque no se entienda que aquello no es más de lo que se dice, que no hay vocablos para declarar cosas tan subidas de Dios, como en estas almas pasan; de las cuales el propio lenguaje es entenderlo para sí y sentirlo y gozarlo y callarlo el que lo tiene. (...) y así sólo se puede decir, y, con verdad, que a vida eterna sabe. (San Juan de la Cruz, Llama de amor viva, canción 2a, verso 4, §§ 20 y 21)

En este primer fragmento, extraído del libro Llama de amor viva, la inefabilidad se refiere claramente a la manifestación divina en un alma ya avanzada en su jornada espiritual. Tal manifestación se traduce en términos sensibles, a partir de una metáfora táctil, a saber, un "toque" amoroso. De este modo, es inefable la propia experiencia mística, comprendida como la inestimable conexión entre el sujeto humano y un "objeto" que

“(...) Jankélévitch atravesó el siglo XX en una condición de total 'inactualidad'. Leyendo y estudiando los filósofos que amaba, Platón, Plotino, Pascal, Schelling, pero releyéndolos de manera completamente distinta de la desconstrucción reinante y sin desdeñar de trabajar con autores menos frecuentados, para no decir marginalizados por el pensamiento dominante: Séneca, Epicteto, Juan de la Cruz, Jacob Boehme, Angelus Silesius, Gracián, La Rochefoucauld, Fénelon, hasta Chestov y Simmel -para citar solo algunos" (Lisciani-Petrini, Charis 23).

Por ejemplo, la locución "espressivo inexpressivo", que, empleada como título del segundo capítulo de La música y lo inefable, intenta acercarnos al modo particular con que la música se expresa. 
sobrepasa en mucho la condición de objeto. Sin embargo, la inefabilidad del toque sentido por el alma revela simultáneamente algo de la realidad que lo ofrece. De hecho, el parentesco entre las elevadas noticias místicas y la naturaleza divina es una constante en los escritos sanjuanistas.

La inefabilidad atribuida a Dios parece aquí encontrar una sencilla justificación. El Verbo, causador del toque, "es ajeno de todo modo y manera, y libre de tomo y figura y accidentes". Como adelantamos en la introducción de nuestro texto, el Verbo es "oscuro", es decir, "no cabe debajo de imagen ni forma" (Subida del Monte Carmelo, libro 2, capítulo 16, § 7). Según la concepción aristotélica, vigente en la filosofía escolástica y absorbida por el santo español, solo seríamos capaces de representar un objeto en el momento en que lo asociamos a determinadas categorías. Por consiguiente, aquello que no posee rasgos característicos queda solo con su núcleo, su sustancia, insuficiente para configurarlo visual o discursivamente. ¿Cómo representar el Dios que, al proclamarse simplemente como "Yo soy lo que soy" (Ex 3,14), no nos provee de los predicados necesarios para la constitución de un juicio, para el desarrollo de un discurso?

No obstante, la ausencia de "modos" y "maneras", verificada en el Verbo, no impide el reconocimiento de una "cualidad" en el toque divino. Este es sutil y delicado, como el "silbo de aire delgado" que se manifestó un día -recuerda el santo (Llama de amor viva, canción 2, verso 3, § 17)- al Profeta Elías (3Re 19,11).

Por tanto, notamos que en el pasaje examinado la inefabilidad incluye algo más que lo inexpresable. Si en algunas circunstancias la grandiosidad o la potencia inconmensurable identificada en lo sublime y en lo numinoso se comprende como inefable por sobrepasar a su modo nuestras posibilidades representativas, aquí es la extrema delicadeza que no se puede captar por un lenguaje construido sobre conceptos un tanto groseros.

Más que por San Juan de la Cruz, llegamos a esta última conclusión por intermedio de un filósofo contemporáneo, Vladimir Jankélévitch, quien constata con frecuencia la inadecuación del entendimiento y del lenguaje humanos frente a sus temas de estudio, por demás impalpables, sutiles, evanescentes. De este modo, al pretender examinar el tiempo, la música, el amor, la inocencia, el breve instante en el cual se realiza un genuino acto de caridad, Jankélévitch descubre que "ninguna inteligencia es bastante perspicaz, bastante aireada para rozar con su tangencia lo intangible casi-nada (presque-rien)" (Le Je-ne-sais-quoi... 73) ${ }^{3}$. Por consecuencia, tampoco el lenguaje a partir del cual se ordena la razón discursiva no podría revelarse suficientemente agudo y matizado para abordar tales temas. Y así, resta al pensador recurrir no "al fondo de la filosofía clásica, sino antes al registro de la devoción y hasta al repertorio incandescente de la mística" (Berlowitz y Jankélévitch 50) ${ }^{4}$.

Además de la desproporción entre la sutileza de la experiencia y la tosquedad del lenguaje, el pensamiento jankélévitchiano también nos sugiere una posible relación entre la inefabilidad y la imaterialidad. A pesar de su dimensión físico-acústica, la música, uno de los ejemplos preeminentes de la modalidad positiva de lo inexpresable según el filósofo (lo inefable, según veremos en la tercera sección), suele percibirse como algo

$3 \quad$ Nuestra traducción.

$4 \quad$ Nuestra traducción. 
impalpable, fluido, atmosférico y difuso. Coincidentemente, el toque amoroso descrito por San Juan de la Cruz manifiesta, al lado de la delicadeza, el mismo atributo de la imaterialidad. Como su divino autor, de naturaleza espiritual, el toque no es un objeto sólido, no posee concreción, "ningún bulto ni tomo tiene".

La aproximación a la experiencia, así como a la divinidad que la proporciona, es aquí nuevamente negativa, siguiendo la construcción negativa implícita en el propio concepto de "in-efabilidad". La negación se reitera cuando el santo-poeta declara que "la delicadez del deleite que en este toque se siente es imposible decirse" (nuestro subrayado) y confiesa que preferiría no "hablar en ello, porque no se entienda que aquello no es más de lo que se dice". En otras palabras, el autor es consciente del ineludible riesgo asumido por quien pretende discurrir sobre lo inefable: el lector que no ha pasado por la experiencia puede tomarla como equivalente a su precaria transcripción verbal. Así, junto con las comparaciones y metáforas empleadas ("toque amoroso", "sabor de vida eterna"), el místico debe recurrir al discurso negativo como estrategia para enfatizar el "plus" que su experiencia comporta. Por otro lado, San Juan de la Cruz sabe que, frente al límite del logos, podría igualmente contestar con el silencio al toque inefable, cuyo "propio lenguaje es entenderlo para sí y sentirlo y gozarlo y callarlo el que lo tiene". De hecho, el santo opta por silenciarse al fin de la Llama, que concluye de modo súbito, absteniéndose de declarar los tres últimos versos.

Sin embargo, la opción por el silencio no se condice con la misión de guía abrazada por el santo. A fin de orientar las almas, es menester enumerar y describir las etapas del itinerario espiritual, compuestas por eventos, aprehensiones y noticias, como el propio toque divino, que no se dejan decir plenamente por las palabras. Así, el guía vive la tensión constituida, por un lado, por la consciencia de la precariedad del lenguaje discursivo y, por otro, por la exigencia de orientar el camino hacia lo Sumo Inefable.

En el pasaje analizado, tal vez contribuya para la inefabilidad del camino el carácter subjetivo de quien lo realiza. Así inferimos por el pronombre posesivo asociado al entendimiento místico que, en San Juan de la Cruz, es más que una aprehensión racional. Como explica el poeta, el "lenguaje" de lo inefable es "entenderlo para sí y sentirlo y gozarlo y callarlo el que lo tiene". De este modo, la instrucción es siempre aproximativa, una vez que el guía y cada uno de sus discípulos apreciarán con una distinta cualidad los frutos de la jornada mística. Así, términos como "delicado" o "sabroso" podrían comprehender innúmeros matices, según nos muestra más recientemente el concepto de qualia, desarrollado por el ámbito de la Filosofía de la Mente.

Por fin, nos gustaría subrayar que la conclusión de este primer pasaje se vale de un interesante recurso para enfrentar con vocablos lo inexpresable. Así nos percatamos a partir de la lectura de Susanne Langer, filósofa contemporánea, que, como Jankélévitch, detecta en la inefabilidad uno de los rasgos esenciales de la música y de toda expresión artística. A diferencia de Jankélévitch, Langer no recurre a la tradición mística, sea ella neoplatónica o cristiana, a fin de pensar lo inefable. Sin embargo, sus ideas sobre las posibles formas de articulación expresiva de los sentimientos humanos, "verbalmente inefables" (Langer 26), se aplican con exactitud a algunas estrategias y conclusiones verificadas en la obra del santo español. Según la autora, 
las formas del sentimiento y las formas de expresión discursiva se muestran desproporcionadas, de modo que cualquier concepto exacto del sentimiento y de la emoción no se puede proyectar en la forma lógica del lenguaje literal. La declaración verbal, que es nuestro medio de comunicación más habitual y confiable de comunicación, es casi inútil para transmitir conocimiento acerca del carácter preciso de la vida afectiva. Designaciones crudas como "alegría", "pesar", "miedo" nos dicen tan poco acerca de la experiencia vital como "cosa", "ser" o "lugar" nos dicen acerca del mundo de nuestras percepciones. Cualquier referencia más precisa al sentimiento se hace, en general, junto a la circunstancia que lo sugiere: "un humor de tarde de otoño", "un sentimiento de feriado". (Langer 91) ${ }^{5}$

Retirándonos del campo de la mística, podemos comprobar la tesis de Langer a través de una breve digresión por el territorio musical. Observamos al citar a Jankélévitch, que la música se presenta, sobre todo en su manifestación exclusivamente instrumental, como exponente de lo inefable. No logramos definir o describir sus contenidos expresivos con precisión y eficacia, en la medida en que los eventos musicales no poseen en general, como las palabras, significados decodificables y estables ${ }^{6}$. Así se comprende por qué la caracterización de una pieza instrumental puede limitarse, como en el caso de la referencia a un sentimiento mencionada por Langer, a la mera identificación entre la obra y otro contexto musical. Nos tomamos aquí la libertad para relatar un episodio personal, capaz de ilustrar precisamente este aspecto: tras un concierto de cámara en el que se ejecutó el Trio en Re menor, Op. 49, de Mendelssohn, algunos oyentes músicos de la audiencia comentaron que su segundo movimiento les sonó como un "romance sin palabras" para piano del mismo compositor. Luego, frente a la imposibilidad de describir el contenido "semántico" del Andante del Trio, solo nos restó comparar su atmósfera, sin precisarla, a aquella encontrada en otra obra musical, elaborada a partir de una poética afín. Como el "humor de tarde de otoño", la expresividad de un "romance sin palabras" no trae consigo descripciones. Y así, exige del interlocutor la experiencia previa de la circunstancia referida. Esta es, de hecho, una de las características de lo inefable místico, ya apuntada por William James en sugestiva comparación con la música ${ }^{7}$.

Notamos que algo bastante similar ocurre en la mención al cuarto verso de la segunda canción de la Llama. Incapaz de desmenuzar con palabras el "toque inefablemente

$5 \quad$ Nuestra traducción.

6 Específicamente para Jankélévitch, la música comparte con la divinidad de la Teología mística una naturaleza que no se conforma a las categorías disyuntivas cotidianas (como lo cómico y lo trágico), lo que también refuerza su inefabilidad (Jankélévitch, $L a$ música y lo inefable 110).

7 "De esto se sigue que su cualidad [del estado mental místico] ha de experimentarse directamente, no pudiendo comunicarse ni transferirse a los demás. Por esta peculiaridad los estados místicos son más similares a estados de sentimiento que a los estados intelectuales. Nadie puede aclararle a otro que nunca ha experimentado cierto sentimiento en qué consiste su cualidad o su valor. Se ha de tener oído musical para reconocer el valor de una sinfonía (...)" (James 159; nuestra traducción). 
delicado del Verbo" (Llama de amor viva, canción $2^{\mathrm{a}}$, verso 3 , § 20), el poeta llega, resignado, a la siguiente conclusión: "así sólo se puede decir, y con verdad, que a vida eterna sabe". Aunque, en este contexto, no es posible conocer de antemano el sabor de la vida eterna, solo puede comprender la afirmación aquel que posee, en su "equipaje" espiritual, alguna experiencia de beatitud, a partir de la cual idealiza el deleite superlativo reservado a los electos.

Y de este bien del alma a veces redunda en el cuerpo la unción del Espíritu Santo, y goza toda la sustancia sensitiva, todos los miembros y huesos y médulas, no tan remisamente como comúnmente suele acaecer, sino con sentimiento de grande deleite y gloria, que se siente hasta los últimos artejos de pies y manos. Y siente el cuerpo tanta gloria en la del alma, que en su manera engrandece a Dios, sintiéndole en sus huesos, conforme aquello que David (S1 34,10) dice: Todos mis huesos dirán: Dios, ¿quién semejante a ti?

Y porque todo lo que de esto se puede decir es menos, por eso baste decir, así de lo corporal como de espiritual: que a vida eterna sabe, y toda deuda paga. (Llama de amor viva, canción $2^{\mathrm{a}}$, verso $4, \S 22$ )

Este segundo pasaje, continuación del primero, nos permite reflexionar acerca de una importante característica de la inefabilidad: su relación con la dimensión sensible. Vimos anteriormente que la propia sensación (auditiva, gustativa, táctil, olfativa, visual) también se revela incapturable por conceptos, demasiado universales para aprehender y comunicar su específico matiz. No obstante, podríamos preguntarnos si la inefabilidad de una experiencia mística sería mayor que la inefabilidad meramente sensorial. Tal pregunta, de difícil o casi imposible respuesta, presupone la existencia de grados de expresabilidad e inexpresabilidad, hipótesis que se encuentra implícita en el pensamiento de Vladimir Jankélévitch.

Retomando la inefabilidad del arte sonoro, para el filósofo francés la ejecución y también la apreciación musical se mostrarían más intraducibles que la mera percepción sensible, ya dotada de una cualidad indefinible. Como leemos en La música y lo inefable,

del mismo modo que ninguna lectura puede suplir el amor real por una mujer real, y ninguna descripción, según Proust, por asombrosa que sea, puede dar la idea de Venecia a quienes no han estado allí y no han podido aspirar personalmente su olor, ninguna imaginación puede anticipar personalmente su olor, ninguna imaginación

8 La misma expresión aparece en la Subida del Monte Carmelo (libro 2, cap. 26, § 5), en referencia a la inefabilidad de las noticias acerca de Dios, que, sin la participación de imágenes o de palabras, se revelan al entendimiento. Volveremos justamente a ese capítulo de la Subida en la cuarta sección de este trabajo. 
puede anticipar ni representarse lo indefinible de la Balada en Fa sostenido de Gabriel Fauré sin haberla saboreado. Sin embargo, para aquellos que han tenido bajo sus dedos el misterio de los seis sostenidos, que lo han sentido palpitar sobre las teclas blancas y negras, resonará algo totalmente distinto, de lo que nadie puede dar la idea a otro (...); y el olor mismo de Venecia, aunque sui generis, es una cualidad específica bastante burda al lado de la sutil embriaguez y del delirio irrepresentable, qei'a maniva, que la Balada nos provoca. (Jankélévitch, La música y lo inefable 134)

Aunque el autor no justifique su tesis, aventuramos que el misterio producido por la Balada es más acentuado que el singular olor de Venecia, por el hecho de que la composición musical, además de contener una rica profusión de elementos estéticos (presentados sucesiva y simultáneamente), podría comunicar, como obra de arte, algo de la propia inefabilidad humana que la crea.

En el fragmento citado de La música y lo inefable, la inefabilidad musical es comparada a algo totalmente distinto ("quelque chose de tout autre"), que remite probablemente al concepto de "ganz Andere" empleado por Rudolf Otto (Lo santo: lo racional y lo irracional en la idea de Dios) en referencia a lo numinoso. Por consiguiente, Jankélévitch piensa la experiencia estético-musical a partir de la experiencia religiosa, así como Otto había pensado la segunda a partir de la primera, extrayendo de la categoría de lo sublime las características de lo numinoso.

Volviendo a San Juan de la Cruz, también en él, poeta y místico, ambas experiencias se encuentran (la religiosa y la estética en sentido amplio, como dominio de la sensibilidad). Subrayamos que el "toque amoroso", proveniente del "absolutamente Otro", produce un deleite. Si la divinidad no posee determinaciones que nos permitan describirla afirmativamente, algo se puede decir de positivo (aunque de modo reducido y aproximado) de la "sensación" causada por ella: el toque es sutil y delicado. En este sentido, la inefabilidad atribuida a lo divino, que no resulta de una particularidad innombrable, es más radical que la inefabilidad de la experiencia humana de acercamiento a lo divino.

A su vez, el poeta de Fontiveros parece defender, como vimos, la mayor dificultad en describir el toque místico, sustancial y sutilísimo, que un toque sensible, mensurable y ponderable. En el fragmento de la Llama anteriormente interpretado, solo el toque "de la divina sustancia" se presenta como inefable. Es interesante observar que, en la continuación del texto ahora examinada, al grado más elevado de inefabilidad (o a la manifestación propiamente inefable) corresponde una experiencia de más elevada intensidad. Y tal intensidad repercute indiscutiblemente en el ámbito corporal. Mientras San Pablo desconoce si su rapto al tercer cielo sucedió en el cuerpo o fuera del cuerpo (2 Cor 12,2), San Juan de la Cruz se acerca en este pasaje a su hermana en la orden carmelita $^{9}$, Santa Teresa de Jesús, en cuya experiencia de la transverberación "no deja

9 En la Subida del Monte Carmelo, con todo, la deleitable recepción del conocimiento sobre Dios -y proveniente de Dios- no siempre incluye la participación del cuerpo. Según el santo, estas altas noticias "son tan sensibles, que algunas veces no sólo al alma, sino también al cuerpo hacen estremecer. Pero otras veces acaecen en el espíritu muy sosegado 
de participar el cuerpo algo, y aun harto" (Teresa de Jesús, Libro de la Vida, cap. XXIX, $\S 13)$. El fuerte impacto de la presencia divina en el compuesto psicosomático no nos sorprende en el relato de Teresa, que se siente atravesada por un dardo de oro con un "poco de fuego" en la punta. Sin embargo, es curioso cómo un toque tan delicado puede generar, en el místico de la Noche oscura, un goce tan potente.

De cualquier modo, la dimensión del sentir y de los sentidos se conecta aquí a una experiencia promovida por una realidad más allá de lo sensible. Quizá la inefabilidad no solo sea responsable de la intensidad de la experiencia, sino también que esta última sea responsable de la primera. Lo inefable místico se entrelaza en alguna medida con lo inefable estético en estas bellas líneas de San Juan de la Cruz. Así suele pasar con los poetas, como sugiere otra filósofa contemporánea, María Zambrano, declarada admiradora del místico carmelita:

La poesía, en cambio [al contrario de la filosofía], asentada desde sus orígenes en lo inefable, lanzada a decir lo indecible, no ve amenazada su existencia. Desde el primer instante, se sintió arrastrada a expresar lo inefable en dos sentidos: inefable por cercano, por carnal; inefable también, por inaccesible, por ser el sentido más allá de todo sentido, la razón última por encima de toda razón. Es el drama que humildemente ha conllevado todo poeta; unos entendiéndolo, otros, sin entenderlo.

A esta inefabilidad se consagra la poesía. Y el poeta siente el nexo fortísimo que hay entre ellas; entre la cercanía de su carne y el más alto principio, la más elevada razón; lo que por quedar bajo la razón no puede definirse y lo que por hacer que haya definición no puede quedar bajo ella. (Zambrano 119-120)

Con esta distinción, Zambrano nos ayuda a contestar, más allá del marco sanjuanista, a una de las preguntas fundamentales de este trabajo: ¿a qué se refiere la inefabilidad? Además, la autora nos hace recordar otra instigadora distinción encontrada en la circunscripción no de lo inefable, sino de lo inexpresable.

Según Jankélévitch, en sus textos La música y lo inefable y La muerte, el ser humano enfrenta dos niveles opuestos de inexpresabilidad. Por un lado, reconoce la radical imposibilidad de expresar lo que, por su ausencia de contenido o por su naturaleza insuperablemente inaccesible, no se ofrece, empleando una terminología kantiana, a la "experiencia posible". Este nivel, bautizado de indecible (indicible), tiene como su máximo ejemplo la muerte, absolutamente indescriptible para aquel que pretende hablar

sin estremecimiento alguno, con súbito sentimiento del deleite y refrigerio en el espíritu". (Subida del Monte Carmelo, libro 2, cap. 26, § 8) Eulogio Pacho también nos explica que, en la Noche oscura (libro 2, cap. 1, § 2), tal quietud, sin repercusiones somáticas agitadas y dolorosas, sería característica a la comunicación divina en almas espiritualmente más avanzadas (perfectas). (Juan de la Cruz, Obras completas 591, nota 3). 
sobre su propia muerte. Por otro lado, el filósofo detecta los límites de la palabra frente a experiencias cuya fecundidad desbordante no se deja fijar ni comunicar por los cortos conceptos. Llamado de inefable (ineffable), el antípoda de lo indecible "es inexpresable por ser infinito e interminable cuanto sobre ello hay que decir: éste es el insondable misterio de Dios, éste es el inexpugnable misterio del amor, que es el misterio poético por excelencia" (Jankélévitch, La Musique et l'ineffable 93) ${ }^{10}$. Así, lo inefable no es indecible: la riqueza que contiene y que podemos fruir despierta en nosotros adjetivos, sugerencias, imágenes poéticas. Con todo, estos nunca podrán agotar lo experimentado, hecho que, en este caso, justifica la formulación aun negativa del nivel más que positivo de inexpresabilidad. Como sintetiza el filósofo, "lo expresable-inefable" es lo "expresable al infinito" (93). A partir de tal comprensión de la inefabilidad, el discurso acerca de lo inexpresable positivo pierde su carácter absurdo: aunque lo inefable se revele "'expresable' y 'decible' solo en modos fugaces, equívocos, inexpresivos, puesto que nadie jamás lo expresa verdadera y completamente" (Lisciani-Petrini, "Lo 'charme' della musica" XXXVI), permanece la constante posibilidad de una alusión verbal a él ${ }^{11}$.

Es interesante observar, en este trabajo dedicado a la inefabilidad sanjuanista, que tal posibilidad alusiva también se verifica, de acuerdo con Jean Baruzi, en la obra del santo carmelita. Si las palabras no nos permitiesen descubrir o presentir algo acerca de aquello a que se refieren, su tarea se restringiría a marcar, de modo un tanto tautológico, el carácter incomunicable de la experiencia. Citando el estudioso de San Juan de la Cruz, "se debe comprender que las imágenes y, de manera general, el lenguaje, están solamente destinados a hacernos adivinar otro lenguaje 'que habla de dentro' (Llama de amor viva, canción $1, \S 6$ ) y que ningún vocablo puede pronunciar. El recurso a la inefabilidad no es, aquí, confesión banal de impotencia (Baruzi 415-416) ${ }^{12}$.

Tras este breve paréntesis, se concluye que los conceptos jankélévitchianos de indecible e inefable no equivalen a la distinción formulada por Zambrano en el interior de la inefabilidad. Según el pensador francés, la abundancia de lo inefable permite, como mencionamos, un tratamiento poético. Por otro lado, la fuente inspiradora de lo inefable se opone a la "expiración mortal" (Jankélévitch, La Mort 75) de lo indecible, cuya esterilidad no genera ni palabras en prosa, ni metáforas poéticas, ni formas artísticas. Así, lo "inefable por cercano, por carnal", que desafía el poeta a colocar en palabras lo

$10 \quad$ Nuestra traducción.

11 La fugacidad verificada en el discurso sobre lo inefable corresponde, en Jankélévitch, a un trazo fundamental de su "objeto": la ya citada evanescencia. A primera vista, tal característica de lo inefable jankélévitchiano parece contrastar con lo inefable místico, estable y permanente en su trascendencia. Sin embargo, en la relación entre lo divino y lo humano, dentro de la perspectiva judeocristiana, el primero muchas veces se manifiesta para el segundo de modo evanescente. Basta recordar la búsqueda de la Amada por el Amado en el Cantar de los Cantares $(5,2-8 ; 6,1)$, que inspira el mismo tema en el Cántico espiritual, así como el episodio de los discípulos de Emaús, en que la presencia de Cristo se disuelve en seguida al reconocimiento de su identidad (Lc 24,13-35).

12 Nuestra traducción. 
que es simple (pero rica o exquisita) sensación, no corresponde al nivel jankélévitchiano de lo indecible.

Sin embargo, los topoi de lo infra y suprarracional, de lo infra y supralingüístico de algún modo se mantienen, tal vez debido a una influencia neoplatónica, en ambos autores. La inefabilidad comprendida por Zambrano como "el sentido más allá de todo sentido, la razón última por encima de toda razón” coincide, en Jankélévitch, con la inefabilidad del "insondable misterio de Dios" (nivel del "supra”). Y si el concepto de lo indecible, formulado por el filósofo, no se refiere al ámbito de la materia, de las pulsiones irreflexivas o de la pura sensorialidad, este se acerca todavía a "lo que por quedar bajo la razón no puede definirse". Además de la muerte, Jankélévitch incluye en el registro de lo indecible temas como el hechizo, el mal, la violencia ${ }^{13}$. No hay mucho que decir, por ejemplo, de las atrocidades cometidas por el régimen nazista: como también defiende George Steiner, otro intelectual judío del siglo XX sensible a los límites del lenguaje, estas son "demasiado inhumanas para ese acto definitorio de la conciencia humana que es el discurso" (Steiner 173).

Pedimos licencia para recurrir aquí a una imagen un tanto prosaica que, suscitada por una observación hecha por Étienne Gilson, nos ayudaría a fijar la distinción jankélévitchiana entre los dos niveles de inexpresabilidad. El medievalista francés justifica etimológicamente la sugestiva homonimia, presente en la lengua francesa y también en otros idiomas neolatinos, entre los términos "exprimir" en la acepción de "expresar, manifestar", menos frecuente en el español actual, y "exprimir" como "extraer el sumo de algo" 14 . Así, lo "inexprimible", en el sentido de inexpresable, podría comprenderse bajo dos lógicas diferentes. Por un lado, habría lo "inexprimible" de lo que destituido de contenidos experimentables o de un mínimo de razonabilidad se asemejaría a un limón seco del cual ningún sumo se puede extraer (indecible). Curiosamente, tal imagen no es de todo extraña a San Juan de la Cruz. De acuerdo con el poeta carmelita, aquellos que intentan fijarse en prácticas espirituales más "concretas", como el cultivo de "imágenes y formas y meditaciones" (Subida del Monte Carmelo, libro 2, cap. 12, § 6) en lugar de lanzarse a la pura contemplación, "se llenan", después de algún tiempo, "de sequedad y trabajo por sacar el jugo que ya por allí no han de sacar" (Subida del Monte Carmelo, libro 2, cap. 12, § 7). Por otro lado, encontraríamos lo "inexprimible" en un supuesto limón cuyo sumo se muestra, por su desbordante riqueza, inagotable: empleando el lenguaje sanjuanista, de ese fruto siempre habría algún jugo a sacar (inefable). En este sentido, lo inefable se referiría a una realidad cuyo contenido nunca seremos capaces de exprimir hasta la última gota.

14 'Originalmente, exprimir [expresar] significa 'exprimir', es decir, 'comprimir o apretar para extraer el sumo, el líquido'. De ahí, el sentido se extendió a toda acción de extraer el contenido de un objeto. Es en este sentido que el término se aplica al lenguaje. Por su invisibilidad, se estima que el pensamiento se esconde en el interior del hombre, es decir, en su cabeza; el objeto del lenguaje sería, por lo tanto, extraer, manifestar y comunicar este pensamiento" (Gilson 77; nuestra traducción). 
Tras esta breve consideración, cabría indagar si la inexpresabilidad, en San Juan de la Cruz también se manifestaría en los dos polos identificados por Jankélévitch. Ya sabemos -y todavía lo confirmaremos a lo largo de este estudio- que el polo de la inefabilidad se presenta como uno de los trazos fundamentales de la experiencia mística y como constante en los escritos del santo carmelita. Sin embargo, ¿habría en éstos alguna alusión a lo inexpresable no por el exceso, sino por la ausencia o la irracionalidad verificada en el tema que se pretende abordar? Alejándonos por un momento del nivel de lo inefable para extendernos a la esfera más amplia de lo inexpresable, podríamos mencionar una referencia a lo indecible, según la comprensión jankélévitchiana, en San Juan de la Cruz. Para este, tampoco se muestran expresables los perjuicios causados por el apego de la voluntad a los bienes naturales, especialmente la inclinación "a complacencia y deleite sensual y lujuria" (Subida del Monte Carmelo, libro 3, cap. 22, § 2, p. 463). Explica el místico que tal inclinación, contraria al "misterio de positividad" de lo inefable (Jankélévitch, La música y lo inefable 119),

contiene en sí daños innumerables, aunque no se pueden comprender con la pluma ni significar con palabras, no es oscuro ni oculto hasta dónde llegue y cuánta sea esta desventura nacida del gozo puesto en las gracias y hermosura natural, pues que cada día por esta causa se ven tantas muertes de hombres, tantas honras perdidas, tantos insultos hechos, tantas haciendas disipadas, tantas emulaciones y contiendas, tantos adulterios, estupros y fornicios cometidos y tantos santos caídos en el suelo (...)". (Subida del Monte Carmelo, libro 3, cap. 22, § 3)

Aunque construida en orden inverso, la última sección ha sido motivada por el fragmento que le sirve de conclusión. Sin embargo, la exposición teórica relativa a las dos modalidades de lo inexpresable nos ayudará a profundizar un poco más, regresando ahora al registro de la inexpresibilidad positiva, nuestras consideraciones sobre lo inefable sanjuanista.

En el pasaje de la Subida arriba mencionado, el autor no presenta las justificaciones para la "indecibilidad" del apego a los bienes naturales, que, vinculados a la pura sensorialidad, podrían situarse en un nivel infrarracional. Cabe notar que tal infrarracionalidad no es fecunda, como los estímulos sensibles que cautivan e inspiran al poeta en Zambrano, sino que revelan su insípida aridez en una perspectiva menos inmediata y más madura espiritualmente.

Por otro lado, como ya hemos constatado, San Juan de la Cruz ofrece razones para la inefabilidad de Dios y de la experiencia mística que llegan a coincidir con algunos puntos presentados por la filosofía jankélévitchiana, perspectiva teórica privilegiada por este trabajo. Así constatamos, una vez más, al revisar la siguiente explanación acerca de las revelaciones a las cuales se encuentra sujeto el "alpinista" del Monte Carmelo:

De donde es de notar que este género de noticias se distingue en dos maneras de ellas; porque unas acaecen al alma acerca del Criador, otras acerca de las criaturas, como habemos dicho. Y aunque las unas y las otras son muy sabrosas para el alma, pero el 
deleite que causan en ella éstas que son de Dios no hay cosa a qué le poder comparar, ni vocablos ni términos con qué le poder decir, porque son noticias del mismo Dios y deleite del mismo Dios; que, como dice David (Sal. 39, 6), no hay como él cosa alguna. Porque acaecen estas noticias derechamente acerca de Dios, sintiendo altísimamente de algún atributo de Dios, ahora de su omnipotencia, ahora de su fortaleza, ahora de su bondad y dulzura, etc.; y todas las veces que se siente, se pega en el alma aquello que se siente. Que, por cuanto es pura contemplación, ve claro el alma que no hay cómo poder decir algo de ello, si no fuese decir algunos términos generales que la abundancia del deleite y bien que allí sintieron les hace decir a las almas por quien pasa; mas no para que en ellos se pueda acabar de entender lo que allí el alma gustó y sintió. (Subida del Monte Carmelo, libro 2, cap. 26, § 3)

Es interesante resaltar que la posibilidad de diferentes grados de inefabilidad se confirma en esas líneas. Explica didácticamente el santo que las revelaciones, comprendidas como "inteligencias desnudas en el entendimiento" (Subida del Monte Carmelo, libra 2, cap. 26 , subtítulo), se dividen en dos géneros. Sin embargo, el primero de ellos, referente a una especie de conocimiento no representativo de Dios y a un privilegiado acercamiento a Dios por parte del alma, se revela particularmente inexpresable. Confirmamos así la intuición registrada en la primera sección de este trabajo: la inefabilidad de la experiencia mística resulta, en gran medida, de la inefabilidad de aquel que se comunica a través de ella con el sujeto humano. En las palabras del santo, no hay "ni vocablos ni términos con qué le poder decir [a las noticias acerca del Criador], porque son noticias del mismo Dios y deleite del mismo Dios". Y este, además de indescriptible por el lenguaje, se presenta como realidad cuya radical trascendencia en relación con las criaturas, le hace incomparable ("no hay como él cosa alguna"), posición que dificultaría incluso una aproximación no-discursiva (poética o plástica) a lo Sumo Inefable ${ }^{15}$. Sugestivamente, tal comunicación repercute nuevamente en la sensibilidad del místico (en este caso, al menos en sus sentidos espirituales) como un "alto sentir", efecto que también acompaña a la inefabilidad del "no-sé-qué" presentado por el Cántico espiritual B (canción 7, § 9). Bajo esta lógica, la inefabilidad (del "objeto" y de la experiencia) y el deleite (del sujeto) se muestran directamente proporcionales. Respecto a la relación sujeto-objeto, podríamos aún añadir que la dificultad en expresar -y pensar- la experiencia de Dios se acentuaría por la imposibilidad de formular algo sobre lo que no se presenta en separado para un análisis, sino que se confunde con el propio sujeto ("se pega en el alma aquello que se siente"), perdiendo así sus delimitaciones y propiedades objetivas.

Otro aspecto verificado en tal género de revelaciones es la fecundidad característica de lo inefable. Como nos explica Jankélévitch, la "categoría" en cuestión no se refiere simplemente a lo inexpresable, sino a lo que no se deja expresar por completo, a lo "expresable al infinito". La riqueza de las "noticias" aproximativamente descritas se

15 El carácter incomparable de Dios, aspecto que contribuye para su inefabilidad, ya se encontraba implícito en el pasaje de la Llama trabajado en la segunda sección, cuando el santo cita la pregunta de Salmo: "Dios, ¿quién semejante a ti?" (S1 34,10). 
manifiesta por un término en especial: abundancia. Al reconocerla, el santo constata que tal experiencia nunca se reducirá al discurso, siempre parco y contingente. Y así aclara que el uso de los términos generales del lenguaje en referencia a esa "pura contemplación" no puede tener como objetivo "acabar de entender lo que allí el alma gustó y sintió".

Reencontramos aquí una de las preguntas iniciales de este trabajo. ¿Cuál entonces sería el sentido de tematizar lo inefable? Al inicio del capítulo 26, de donde extraemos el fragmento examinado en esta sección, confirmamos la ya mencionada necesidad didáctica de esbozar al peregrino espiritual un mapa cuyos territorios no siempre poseen contornos definidos. Según el carmelita español,

[p]ara hablar propiamente de esta inteligencia de verdades desnudas que se da al entendimiento, era necesario que Dios tomase la mano y moviese la pluma; porque sepas, amado lector, que excede toda palabra lo que ellas son para el alma en sí mismas. Mas, pues yo no hablo aquí de ellas de propósito, sino sólo para industriar y encaminar el alma en ellas a la divina unión, sufrirse ha hablar de ellas aquí corta y modificadamente cuanto baste para el dicho intento. (Subida del Monte Carmelo, libro 2, cap. $26, \S 1)^{16}$

Además del propósito pedagógico, la insistencia en expresar verbalmente lo inefable también parece provenir de la fecundidad experimentada. Recordando las palabras del maestro espiritual, "la abundancia del deleite y bien que allí sintieron [aquellos que experimentaron tales noticias] les hace decir a las almas por quien pasa". Es como si el exceso encontrado en la realidad saboreada necesitase extravasarse de alguna forma, y una de ellas es, sin duda, el discurso verbal. En este sentido, el sujeto místico podría concebirse como el vaso que, en continuidad con la palabra humana, no contiene la divinidad desbordante.

A los oídos del santo, tal desbordamiento parece sonar en un emblemático episodio bíblico. Cuando Moisés sube, con las nuevas tablas de piedra, al Monte Sinaí y se reencuentra con el Señor frente a sí, su reacción es alabarlo con múltiples adjetivos: fuerte, misericordioso, clemente, paciente, grande en misericordia y verdadero (Ex 34,6-7). Seguro de que Dios es "expresable al infinito", San Juan de la Cruz interpreta que "no pudiendo Moisés declarar lo que en Dios conoció en una sola noticia, lo dijo y rebosó por todas aquellas palabras" (Subida del Monte Carmelo, libro 2, cap. 26, § 4) (nuestro subrayado).

16 Como observa Eulogio Pacho, en sus notas a las Obras completas de San Juan de la Cruz (edición utilizada como base para nuestros apuntes), este pasaje posee estrecha semejanza con la declaración a la canción 26, § 3 y 4 del Cántico espiritual B (Juan de la Cruz, Obras completas 370, nota 1). Además de la imagen común de Dios o del Espíritu Santo que debe "tomar la mano y mover la pluma" para expresar lo inexpresable, completamos que ambos fragmentos, considerando sus contextos, comparten la idea de una gradación de inefabilidad. En el Cántico, la "interior bodega" evocada por la canción 26 se muestra especialmente inefable por simbolizar el grado más elevado (e íntimo) de conexión con Dios. 
Cabe observar que el exceso divino manifestado en la profusión verbal no es exclusivo del ámbito judeocristiano, sino también figura en otra tradición religiosa, con notoria influencia sobre la visión de mundo sanjuanista y el siglo de oro español. Como intuye Goethe, los noventa y nueve nombres de Alá enumerados por el islamismo podrían comprenderse como una estrategia para enfrentar, por medio del lenguaje, lo expresivamente inexhaurible. Así, conjetura el poeta alemán en su diálogo con Eckermann: "¿qué sabemos de la idea de lo divino, y qué significan todos nuestros conceptos estrechos del Ser supremo? Aunque, como los turcos, le diera cien nombres, me quedaría corto y no habría dicho nada en comparación de tan infinitos atributos" (Eckermann 424).

\section{CONCLUSIÓN}

Cabría ahora retomar, a título de conclusión, las preguntas orientadoras de este trabajo, que intentamos contestar a partir de la lectura de algunos fragmentos de San Juan de la Cruz, discutidos mayormente a la luz del pensamiento de Vladimir Jankélévitch. En primer lugar, hemos visto que la inefabilidad, en los pasajes seleccionados y podríamos decir en toda la obra del santo de Fontiveros, suele referirse tanto a la realidad divina como a la propia experiencia mística. De hecho, ambas se entrelazan: la experiencia se revela inefable una vez que se comunica por medio de ella algo de la naturaleza inefable de Dios. Ésta debe comprenderse como pura sustancia, sin "modos y maneras", y así no se conforma a los predicados y categorías a partir de los cuales el discurso se construye. Tampoco la naturaleza divina se prestaría, por su radical trascendencia sobre las criaturas, a las comparaciones que nos sirven habitualmente para describir el mundo de los fenómenos y nuestras vivencias. Además, la "eterna fuente" excede la condición de objeto, necesaria para nuestro modelo predominante de conocimiento, manifestándose simultáneamente incognoscible e inexpresable. Aparte Dios y la experiencia mística, también la sensación corporal, conectada a la segunda, se podría insertar en el nivel de lo inefable, como goce indescriptible.

Por otro lado, hemos constatado que la inefabilidad tematizada por el poeta carmelita incluye las siguientes características: repercute en la sensibilidad, provocando un elevado e intenso "sentir"; no posee volumen, es imaterial, sutil y delicada; conmueve el sujeto con una cualidad única e intransferible; se comunica de modo abundante e inagotable. Algunas de estas características justifican igualmente la inefabilidad afirmada en las "declaraciones" del santo. Es tan alto el "sentir" que sobrepasa las palabras, pobres para la expresión de lo afectivo; la sutileza de lo vivido no se puede traducir en un discurso tosco y poco matizado; la particularidad del "toque" no cabe en los términos generales del lenguaje; la abundancia de lo "expresable al infinito" no se contenta con las parciales formulaciones lingüísticas. Al lado de las características que acompañan nuestro tema, hemos descubierto que no solo Jankélévitch, sino también San Juan de la Cruz coinciden al atribuir una gradación a las realidades inefables. En el caso del místico, la mayor inefabilidad se verifica, primeramente, en el propio Dios, y, segundamente, en los momentos de contacto más cercanos entre el ser humano y el Sumo Inefable, mientras, 
para el filósofo, la inefabilidad del contacto con la obra de arte sobrepasa la cualidad indefinible de la pura sensación ${ }^{17}$. La distinción terminológica jankélévitchiana entre los dos niveles opuestos de lo inexpresable, revisada con el reto de una mejor comprensión del concepto de inefable, también nos ha mostrado que la obra sanjuanista contempla al menos un ejemplo de lo inexpresable negativo, a saber, de lo indecible.

En cuanto a las formas de lidiar expresivamente con lo inefable, hemos identificado que el discurso místico se debe establecer seguido del reconocimiento de su precariedad y de su límite (e incluso de la preferencia declarada por el autor de no hablar sobre lo que "altísimamente" siente). También hemos verificado algunas metáforas y comparaciones, expuestas de modo afirmativo, como el "toque amoroso", el "sabor de vida eterna", el "silbo de aire delgado", aunque el propio santo subraya contradictoriamente el carácter incomparable de lo inefable, que, por otro lado, legitima la constante presencia de construcciones negativas. La abundancia propia a la inefabilidad contribuye quizá para la oscilación entre la tentación de abstenerse, tendiendo al silencio, y la profusión de textos que brotan no solo de la experiencia, sino también de los poemas que sirven de base a las "declaraciones" en prosa. Y, frente a la imposibilidad de nombrar las resonancias espirituales del alma, hemos aun encontrado la estrategia, detectada por Langer, de simplemente citar, sin describir, la circunstancia vinculada a lo inexpresable.

Por fin, hemos reiterado el propósito didáctico de la comunicación verbal de lo inefable, asumido por aquél que se propone guiar las almas por un camino y hacia un término misteriosos para el entendimiento y el lenguaje humanos. También la abundancia de la experiencia saboreada por el místico justifica la necesidad, probablemente incontrolable, de extravasar lo que le sobrepasa. Además, el callarse comporta un riesgo: si decir puede limitar lo vivenciado a lo dicho, el no-decir puede equipararlo, a los ojos ajenos, al vacío, a la esterilidad indecible. Y como la experiencia mística dice respecto a lo inefable, “expresable al infinito", el místico puede todavía aludir a ella verbalmente, haciéndonos presentirla, reconocerla y acogerla.

Tras este breve recorrido, tenemos consciencia de que mucho queda por decir sobre lo inefable en el santo poeta. Esperamos retornar en algún momento al presente tema, para así vislumbrar nuevos matices de la inefabilidad mística y de la inefabilidad latente en la palabra sanjuanista. De cualquier manera, el más largo texto no será capaz de agotar un "objeto" de estudio que se caracteriza por su sobreabundancia. Al reflexionar acerca de lo inefable, como bien lo sabía San Juan de la Cruz, siempre habremos de encontrar un "resto" (Cántico espiritual B, canción VII, § 9). Y este "resto", tanto en lo místico como en lo poético, es un exceso. A veces es el sumo copioso que salpica sobre nosotros sin

17 Aunque no tuvimos oportunidad de verificar en este trabajo, es importante mencionar que la estética musical jankélévitchiana también defiende una gradación de inefabilidad entre diferentes modos de expresión. Partiendo del discurso demostrativo, de carácter unívoco, pasando por la poesía, que se abre a ambigüedades semánticas apoyada todavía en definiciones verbales preestablecidas, y llegando al fin a la música, a la cual podemos atribuir infinitos significados, el filósofo observa un crescendo en términos de inefabilidad. 
que lo podamos retener, otras es el misterio presentido, pero para siempre resguardado, en el fruto saboreado.

\section{BIBLIOGRAFÍA}

Baruzi, Jean. Saint Jean de la Croix et le problème de l'expérience mystique. Édition revue et corrigée avec les deux préfaces de Jean Baruzi (1924 et 1931). Introduction d'Émile Poulat. Paris: Salvator, 1999.

Berlowitz, Béatrice y Vladimir Jankélévitch. Quelque part dans l'inachevé. Paris: Gallimard, 1978.

Eckermann, J. P. Conversaciones con Goethe. Estudio preliminar de Francisco Ayala. Barcelona: Océano, 2016.

Gilson, Étienne. Introdução às artes do belo: o que é filosofar sobre arte? Tradução: Érico Nogueira. São Paulo: É Realizações, 2010.

James, Williams. The varieties of religious experience: a study in human nature. Lexington (KY): Pacific Publishing Studio, 2010.

Jankélévitch, Vladimir. De la musique au silence. v. 1. Fauré et l'inexprimable. Paris: Plon, 1974. La Mort. Paris: Flammarion, 1966.

La música y lo inefable. Prólogo de Arnold I. Davidson. Traducción de Rosa Rius

y Ramón Andrés. Barcelona: Alpha Decay, 2005. La Musique et l'ineffable. Paris: Seuil, 1983.

Le Je-ne-sais-quoi et le Presque-rien. v. 1. La Manière et l'occasion. Paris: Seuil, 1980.

Juan de la Cruz, Santo. Obras completas. Séptima edición preparada por Eulogio Pacho. Burgos: Monte Carmelo, 2000 (Maestros espirituales carmelitas, 3).

Langer, Susanne. Problems of art: ten philosophical lectures. New York: Charles Scribner's Sons, 1957.

Lisciani-Petrini, Enrica. Charis: essai sur Jankélévitch. Traduction d'Antoine Bocquet. Paris/ Milano: Vrin/Mimesis, 2013.

Lo "charme" della musica. In: Jankélévitch, Vladimir. La musica e lo ineffabile. Traduzione e introduzione di Enrica Lisciani-Petrini. Napoli: Tempi Moderni, 1985.

Steiner, George. Lenguaje y silencio: ensayos sobre la literatura, el lenguaje y lo inhumano. Traducción de Miguel Ultorio, Tomás Fernández Aúz y Beatriz Eguíbar. Barcelona: Gedisa, 2013.

Teresa de Jesús, Santa. La Vida; Las Moradas. S.1.: PML, 1995.

Zambrano, María. Filosofía y poesía. 4a ed. México: Fondo de Cultura Económica, 1996. (Filosofía). 